\title{
Towards an Integrated Framework for Knowledge Worker Productivity
}

\author{
A.T. Molekoa and J.A. van der Poll
}

\begin{abstract}
In the growing knowledge economy, the number of Knowledge workers are becoming the largest single group in the work force of every developed country. This has necessitated the increased need and higher performance of the knowledge workers by the respective organisations to come up with innovations and solutions that will make the companies profitable. Whilst the knowledge workers come at a higher cost than the manual workers, their scarce skills also need to be fully utilised in order to deliver value, productively. Therefore, the central challenge is no longer to make manual workers more productive - the central challenge now becomes how to make knowledge workers more productive.

The current body of knowledge is outdated, broke off due to the complexity of the problem and most authors focussed on specific productivity output factors. The current research posits that for knowledge workers to productively transform the inputs to outputs, their degree of foundational practices would prescribe their level of productivity. The author focusses on foundational practices necessary to stimulate higher levels of knowledge productivity.
\end{abstract}

Keywords - Foundational Practices, Information Technology, Integrated Productivity Framework, Knowledge Intensive Organisations, Knowledge Worker, Knowledge Worker Productivity.

\section{INTRODUCTION}

For the last two hundred years, neo classical economics has recognised only two factors of production: labour and capital (Hendarman and Tjakraatmadja, 2012). They also confirmed that nowadays information and knowledge are replacing capital and energy as the primary wealth creating assets. The authors further noted that technological developments have transformed wealth-creating work from physically-based to knowledge-based. Therefore, technology, knowledge as well as innovation are now the key factors of production.

In 1920, the ratio of manual workers to knowledge workers (KWs) was 2:1 as noted by (Davenport, 2003) and yet by 1980, the ratio was $1: 2$. This growing trend necessitates a thorough research in order to advance literature.

Manuscript accepted on 14 October 2019. This work was supported in part by the Banking Sector Education and Training Authority (BankSETA).

A.T. Molekoa is with the University of South Africa (Unisa), Graduate School of Business Leadership (SBL), Midrand, South Africa

J.A. van der Poll is with the University of South Africa (Unisa), Graduate School of Business Leadership (SBL), ICT Management, Midrand, South Africa.

\section{A. Knowledge worker evolution}

Given the increasing importance of knowledge workers in the current "knowledge economy", improved understanding of how knowledge work can be supported ought to be useful to organizations [3].

A fundamental challenge in knowledge worker productivity measurement is the ambiguous definition of knowledge work and the continuously changing role of the knowledge worker [4]. Since the content of work varies among personnel, productivity is generally hard to capture with a single measurement method.

There appears to be no common definition of knowledge worker productivity as several scholars viewed them differently as noted below from the summary of literature:

- a person who has knowledge important for the organization and is often the only person who has it; they can use the knowledge in work [5];

- People with high degrees of expertise, education, or experience. Davenport says that the primary purpose of a knowledge workers' job involves the creation, distribution, or application of knowledge [6];

- knowledge workers are people who work in knowledge intensive organizations, R\&D, and high-tech companies [7];

- managers, people in technical and professional occupations and associate professionals [8];

- knowledge workers depend on their knowledge and ability to learn, even though they work with their hands [8].

Based on the review of the definitions presented in the literature and the relevance to the research, the researchers formulated the following research working definition of a knowledge worker as:

Someone who transforms insights, information or current knowledge through a linear or non-linear process of creation, distribution and application to produce a product or deliver a service or create new knowledge (Synthesized by the researchers).

The reasons for this particular definition are:

- It caters for all levels of complexity that the knowledge worker can undertake, either individually or collaboratively.

- The methodology of the transformation of inputs to outputs is not restricted, as knowledge workers can generate novel solutions or combinations of unrelated ideas to yield new solutions.

- It is not industry bound. 


\section{B. Knowledge worker evolution}

The phenomenon of knowledge worker surpassing the manual workers has been developing for a number of years, as shown by the study in the manufacturing sector of the United Kingdom [9] in fig. 1.

Fig. 1 shows that the number of non-production employees outnumbered the number of production employees in the Total Manufacturing sector in the United Kingdom between the years of 1970 to 2005 .

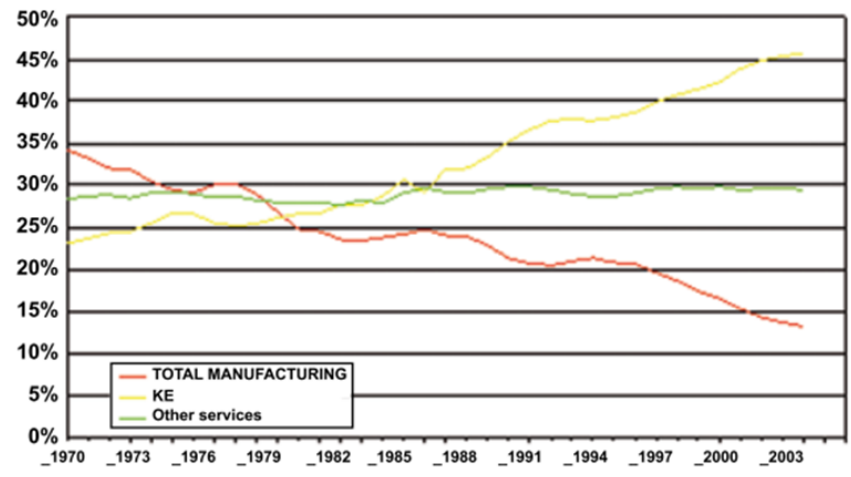

Fig. 1. Growth of knowledge economy in the UK 1970-2005

The number of production workers has been declining over the past decade whilst the number of non-production workers increased. With the increasing number of non-production workers (mainly in the Knowledge based Economy) the question has been "how productive are these workers?" It's easier to measure the output of production employees but difficult to measure the output of non-production workers as their output is elusive e.g. a managerial productivity.

It was also found in the United States of America that the number of information workers has already surpassed non-information workers (Jääskeläinen and Laihonen, 2013b). (Davenport, 2006) also linked the observation to the United States and other leading economies, as he noticed that a high proportion of knowledge workers come from those settings.

Figure 2 directly supports this evolution as its shown in the composition of workers in the United States of America from 1850 to 2010 . The volume of knowledge workers (also referred to as white collar workers) has been growing sharply while the farming volume of workers has declined rapidly. Service jobs remained fairly constant throughout the same period.

Reference [11] narrowed down this observation to the more industrialized countries seemingly to relying more and more on the productivity of the knowledge workers than on advances in production equipment.

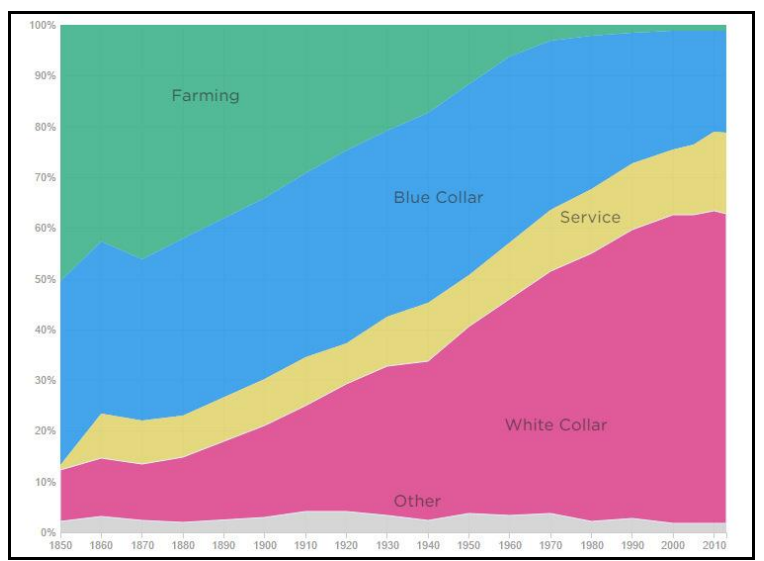

Fig. 2. Composition of U.S. Job Market over the Last 150+ Years [12]

\section{THE PROBLEM STATEMENT AND RESEARCH QUESTIONS}

Reference [13] summarizes the work processes of knowledge workers as hidden. Its process is one where the observer cannot see how a knowledge worker uses knowledge when working. Knowledge workers often possess knowledge that is not widely available, and even their managers do not have it.

Reference [14] re-emphasized the problem as having to measure the productivity of a group of workers who do not produce an obviously measurable, tangible output.

Hence the research problem statement is framed as:

The absence of an integrated framework for assessing knowledge worker productivity in knowledge intensive organizations, has led to difficulties in improving knowledge worker productivity, thereby impacting an organization's competitive advantage.

The complete research envisages to encompass all the research questions (RQs) however only two are covered in this paper, namely:

RESEARCH QUESTION 1: What factors are important in assessing Knowledge Worker Productivity (KWP)?

RESEARCH QUESTION 2: What are the existing and relevant frameworks or models being used to assess KWP?

RESEARCH QUESTION 3: What process-related factors are considered important by Knowledge Workers in making them Productive?

RESEARCH QUESTION 4: What are the practical implications for organizations in improving knowledge worker productivity?

\section{RESEARCH QUESTION 1: FACTORS THAT ARE IMPORTANT IN ASSESSING KNOWLEDGE WORKERS}

\section{A. The importance of knowledge workers}

In South Africa, Knowledge Workers are a growing part of the South African workforce, the data from the South African statistics provided evidence that the Services sector was the largest contributor to Gross Domestic Product in 2017 [15] at 
$67.5 \%$ when compared to agriculture (2.8\%) and industry $(29.7 \%)$.

Reference [16] also found that South Africa is becoming less competitive owing to lack of skills, for example the limited availability of knowledge workers such as engineers. With only $44.6 \%$ of skilled workers receiving any form of training, South Africa is not investing in the small knowledge worker population [16].

Therefore, improving the performance and productivity of the few skilled workers becomes even more important.

The highest occupational demand in the country was managers followed by professionals whilst the lowest were machinery operators and drivers followed by elementary workers and sales workers. If prosperity and even survival depend on knowledge worker productivity [17], then organizations in South Africa need to address issues concerning knowledge workers and their productivity.

A deeper view of table I, reinforces the point that between 2011 and 2012, more Managers and Professionals accounted for a combined $61.9 \%$ of the vacancies in any other group in the South African labor market. It can be summated that South Africa has fewer knowledge workers than what the labor market can absorb.

The total percentage vacancies for manual workers only is a combined 3.8\%, which reveals that South Africa has absorptive capacity for such workers in comparison to the knowledge workers.

Therefore, improving the performance and productivity of the fewer skilled workers, specifically knowledge workers, becomes even more important.

Reference [18] also warns that the growing importance of knowledge work would change power relations in organizations. Firstly, managers used to be the people who had more knowledge, more decision-making rights and the right to control their subordinates. Secondly, the tacit knowledge that knowledge workers have is difficult to share and show, thereby putting organizations at risk when such workers leave. These organizations are more likely to retain only a fragment of the knowledge worker's knowledge.

KWs are the source of growth in most organizations; they come up with new business models, innovative products and services. If an organization is to be successful, it needs to be very good at improving their Asset's (Knowledge Workers) productivity.
TABLE I: QUARTERLY PERCENTAGE OF VACANCIES BY OCCUPATIONAL GROUP, 2011/2012 [19]

\begin{tabular}{|c|c|c|}
\hline $\begin{array}{l}\text { Occupational } \\
\text { groups }\end{array}$ & $\begin{array}{l}\text { Percentage of } \\
\text { vacancies } \\
2011 / 2012\end{array}$ & $\begin{array}{c}\text { Researcher } \\
\text { analysis } \\
\text { Manual vs } \\
\text { knowledge worker }\end{array}$ \\
\hline Manager's & $25.5 \%$ & $\begin{array}{l}\text { Knowledge } \\
\text { workers }\end{array}$ \\
\hline Professionals & $36.4 \%$ & $\begin{array}{l}\text { Knowledge } \\
\text { workers }\end{array}$ \\
\hline $\begin{array}{l}\text { Technicians and } \\
\text { Trade Workers }\end{array}$ & $9.6 \%$ & $\begin{array}{c}\text { Manual \& } \\
\text { knowledge workers }\end{array}$ \\
\hline $\begin{array}{l}\text { Community and } \\
\text { Personal Service } \\
\text { Workers }\end{array}$ & $6.9 \%$ & $\begin{array}{c}\text { Manual \& } \\
\text { knowledge workers }\end{array}$ \\
\hline $\begin{array}{l}\text { Clerical and } \\
\text { Administrative } \\
\text { Workers }\end{array}$ & $15.1 \%$ & $\begin{array}{c}\text { Manual \& } \\
\text { knowledge workers }\end{array}$ \\
\hline Sales Workers & $2.6 \%$ & $\begin{array}{l}\text { Knowledge } \\
\text { workers }\end{array}$ \\
\hline $\begin{array}{l}\text { Machinery } \\
\text { Operator's and } \\
\text { Driver's }\end{array}$ & $1.8 \%$ & Manual workers \\
\hline $\begin{array}{l}\text { Elementary } \\
\text { Workers }\end{array}$ & $20 \%$ & Manual workers \\
\hline Total & $100 \%$ & \\
\hline
\end{tabular}

B. Challenges in assessing knowledge workers

Measuring KW productivity is hard, e.g. "When it comes to knowledge workers, we pretty much hire smart people and leave them alone. No quality measurements, no Six Sigma, no reengineering. We haven't formally examined the flow of work, we have no benchmarks, and there is no accountability for the cost and time these activities consume. As a result, we have little sense of whether they could do better" [20].

Reference [6] described the leader's challenge today as "Increasing the Productivity of knowledge workers is today's leader's great challenge. If we can show the kinds of gains in productivity with knowledge workers that we've been able to achieve with manual labor (production workers are 50 times more productive than they were 150 years ago!), the potential for a company today to achieve and sustain competitive advantage is significant" [6].

References [21] and [22] observed that because of the impact of KWs in the economy's productivity, they are perceived as an important area of opportunity and are starting to be included in organizational strategic plans to improve productivity.

Measuring the knowledge workers is difficult as their activities are not easily visible during the process and hence management is less in control of their activities [23]. This state has resulted in reduced focus on the knowledge worker in the enterprise [2].

The researchers have also observed that much of literature in this area are dated, as the research broke off due to the complexity of the problem and several authors using existing and outdated productivity frameworks to improve on knowledge worker productivity with little success. 


\section{Factors important in assessing knowledge workers}

There are various ways to study knowledge worker productivity. Knowledge workers have the best understanding of the tasks they perform, their importance and of the potential metrics that could help assess their Productivity [24].

The factors affecting productivity are commonly classified into inputs, processes (transformation of inputs into outputs) and outputs [25].

The current research anticipates looking at the process perspective to the productivity challenge i.e. process-related factors to KWP. Based on the research working definition, the researchers believe that examining and controlling the inputs through a focus on process factors, would yield sustainable outputs, given that the process factors are consistent.

That said, the true improvements can only be seen in the outputs, hence a reflection and discussion of outputs would also be considered.

Based on a literature review by the researchers over various productivity and knowledge worker research literature of the past 60 years, table II summarizes the process factors that are important in assessing knowledge workers. Many of the factors in table II are by their nature intangible and qualitative. Table II also shows the focus of the research (i.e. processes) in order to assess KW productivity. These six factors have sub-elements that various authors have cited. The researchers have categorized the various authors' sub-elements to come up with table II.

The descriptions of the factors are defined as:

1) WORKPLACE SETTING

The setting of the workplace for the knowledge worker is important as it impacts on their productivity and well-being. This includes the infrastructure provided, comfort, occupational density, the need for privacy to team composition and how the working environment is controlled.

\section{2) ORgANIZATIONAL ENVIRONMENT}

The way work environments are organized in an organization influences the productivity of knowledge workers. References [25] - [28] have confirmed the importance of organizational culture, rewards and trust among other sub-elements to influence $\mathrm{KW}$ productivity.

\section{3) SELF-MANAGEMENT}

More and more people in the workforce - and mostly knowledge workers - will have to manage themselves [17]. Reference [33] refers to the practice of self-management to give importance to the KW focusing on their 'internal black box' in order to enhance their productivity.

\section{4) LEADERSHIP}

The relationships with the organizational leader impact on the productivity of the KW [31]. Reference [31] confirms that the leadership task will need to be refined to focus on clarifying the 'tasks' as opposed to directing the $\mathrm{KW}$, as they know best their work.

\section{5) INFORMATION TECHNOLOGY INTERVENTIONS}

Information technology interventions talk to tools, processes and systems that can enhance the KW's efficiency. The deployment of such interventions assists the KW.

\section{6) INNOVATIVENESS}

To fully leverage the effectiveness of the KW, innovation has to be part of the knowledge work [27].

TABLE II: THE RUDIMENTARY FRAMEWORK'S PRODUCTIVITY FACTORS CONSIDERED (SOURCE: SYNTHESIZED BY RESEARCHER)

\begin{tabular}{|c|c|c|}
\hline $\begin{array}{l}\text { Productivity } \\
\text { perspective }\end{array}$ & Factors to KW productivity & Authors \\
\hline INPUTS & $\begin{array}{c}\text { Insights, Information or Current } \\
\text { Knowledge }\end{array}$ & $\begin{array}{l}\text { Synthesized } \\
\text { by researcher }\end{array}$ \\
\hline \multirow{6}{*}{$\begin{array}{l}\text { PROCESSES } \\
\text { (linear or } \\
\text { non-linear } \\
\text { process) }\end{array}$} & $\begin{array}{l}\text { 1) WORKPLACE SETTING } \\
\text { Physical location, virtual (IT) } \\
\text { and social workplace and } \\
\text { Working environment, } \\
\text { Knowledge sharing, Team } \\
\text { structure / composition. }\end{array}$ & $\begin{array}{l}\cdot[26] \\
\cdot[10] \\
\text { - }[25]\end{array}$ \\
\hline & $\begin{array}{l}\text { 2) ORGANIZATIONAL ENVIRONMDNT } \\
\text { Organizational culture, } \\
\text { information sharing, } \\
\text { collaboration, Social interaction } \\
\text { and cohesion, Training \& } \\
\text { development, Positive rewards, } \\
\text { opportunity, trust. }\end{array}$ & $\begin{array}{l}\cdot[26] \\
\text { - }[25] \\
\text { - }[27] \\
\text { - }[17] \\
\text { - }[28]\end{array}$ \\
\hline & $\begin{array}{l}\text { 3) SEF-MANAGEMENT } \\
\text { Self-efficacy, motivation, } \\
\text { autonomy, Task identification, } \\
\text { skills, knowledge, Management } \\
\text { of professional's own work, } \\
\text { Timeliness, prioritization. }\end{array}$ & $\begin{array}{l}\cdot[28] \\
\cdot[29] \\
\text { - }[30] \\
\text { - }[31]\end{array}$ \\
\hline & $\begin{array}{l}\text { 4) LEADERSETP } \\
\text { Manager relationship and } \\
\text { support, feedback, } \\
\text { transformational leadership, } \\
\text { Task definition \& goal clarity, } \\
\text { job design } \\
\end{array}$ & - [31] \\
\hline & $\begin{array}{l}\text { 5) INFORMATION TECHNOLOGY } \\
\text { INTERVEMTIONS }\end{array}$ & $\begin{array}{l}\cdot[25] \\
\cdot[32]\end{array}$ \\
\hline & $\begin{array}{l}\text { 6) INNOVATIVIESS } \\
\text { Professional recognition, } \\
\text { affiliations, contribution }\end{array}$ & $\begin{array}{l}\cdot[17] \\
\cdot[27]\end{array}$ \\
\hline OUTPUTS & $\begin{array}{l}\text { Product or Deliver a Service or } \\
\text { Create New Knowledge }\end{array}$ & $\begin{array}{l}\text { Synthesized } \\
\text { by researcher }\end{array}$ \\
\hline
\end{tabular}

The discussions in this section provides an answer to our RESEARCH QUESTION 1.

\section{RESEARCH QUESTION 2: WHAT RELEVANT MODELS ARE BEING USED TO ASSESS KNOWLEDGE WORKERS}

\section{A. Introduction}

It is hard to design a single index comprehensively capturing all the aspects of productivity in complex services [32]. Even if this is achieved, there is a risk that the result is too complex and difficult to use in daily management. Various productivity measures may act as a part of balanced performance measurement systems based on frameworks such as a Balanced Scorecard.

However, with a multidimensional measurement approach it is possible to simultaneously examine quantity and quality as well as tangible and intangible aspects of service provision.

There are various ways to the study of knowledge worker productivity. The knowledge worker has the best understanding of the tasks they perform, their importance and of the potential 
metrics that could help assess their Productivity [24]. Hence the focus on the processes necessary to improve the $\mathrm{KW}$ productivity.

\section{B. Existing models to assess $K W$ productivity}

As table III shows, there is no single unified approach to KW productivity measurement, however, the Taylorism approaches have had limited results as highlighted by [17].

TABLE III: THE USE OF PRODUCTIVITY FACTORS IN CONCEPTUAL MODELS METHODOLOGIES (SUMMARIZED BY THE RESEARCHER)

\begin{tabular}{|c|c|c|c|c|c|c|c|c|c|c|c|c|}
\hline \multirow[b]{2}{*}{$\begin{array}{l}\text { Conceptual models } \\
\text { to assess knowiedge } \\
\text { worker productivity }\end{array}$} & \multicolumn{12}{|c|}{ Productivity dimensions of focus in their research } \\
\hline & 部 & 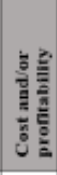 & 竞 & 产 & 这 & 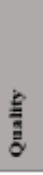 & $\frac{g}{\grave{n}}$ & 要 & 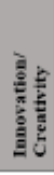 & 递 & 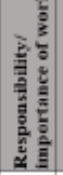 & $\begin{array}{l}\mathrm{S} \\
\mathrm{U} \\
\mathrm{M}\end{array}$ \\
\hline $\begin{array}{l}\text { Mundel's model } \\
\text { [35] }\end{array}$ & $x$ & & & & & & & & & & & $\underline{1}$ \\
\hline $\begin{array}{r}\text { Bumbarger's model } \\
\text { [36] }\end{array}$ & $x$ & & & $x$ & & & & & $x$ & & & $\underline{\mathbf{3}}$ \\
\hline $\begin{array}{l}\text { Smith's model } \\
\qquad[37]\end{array}$ & & $\boldsymbol{x}$ & & & & & & & & & & $\underline{1}$ \\
\hline $\begin{array}{l}\text { Gordon's model } \\
\qquad[21]\end{array}$ & $x$ & & $x$ & $x$ & & $x$ & $x$ & $x$ & & & $x$ & 7 \\
\hline $\begin{array}{l}\text { Drucker's model } \\
\qquad[17]\end{array}$ & $x$ & & & $x$ & $x$ & $x$ & $x$ & $x$ & $x$ & & & $\underline{7}$ \\
\hline TOTAL & 4 & $\underline{1}$ & $\underline{1}$ & $\underline{3}$ & $\underline{1}$ & $\underline{2}$ & $\underline{2}$ & $\underline{2}$ & $\underline{2}$ & $\underline{0}$ & $\underline{1}$ & \\
\hline
\end{tabular}

Table III indicates the number of times the productivity dimensions are used against the five author's conceptual models. From table III, [21] and later [17] emanated models that covered more productivity dimensions than the other three authors.

The top most covered productivity dimensions were (in order of importance):

A. quantity,

B. autonomy,

C. quality, effectiveness, customer satisfaction \& innovation / creativity.

Other notable Productivity Methods by various researchers have been summarized by [10] in Table III.

An outline of what the five models entail in measuring knowledge worker productivity follows:

1) MUNDEL MODEL

Reference [33] states that to provide a start to quantifying the level of work the knowledge worker does, the following questions need to be addressed:

a) What is the objective of the task?

b) What are the outputs that need to be produced to accomplish the task?

c) How can the outputs be counted?

d) How much and what kind of resources are needed to produce the outputs?

e) What is a feasible and desirable operating plan for the next time period?

f) To what extent can the measures be replicated and standardized (maturity)?

\section{2) BUMBARGER MODEL}

Reference [34] conceptualizes an operation function analysis methodology in order to expedite $\mathrm{KW}$ productivity improvements. It is based on four main factors i.e. it:

a) Has to be demand oriented;

b) Needs an inter-organizational focus;

c) Should promote creativity; and

d) Should encourage independence (do it yourself orientation).

\section{3) SMITH MODEL}

Although [35] suggested using industrial engineering-based analyses and measurement techniques, specific implementation issues such as which factors are more important remain unanswered. Reference [35]-techniques included:

a) work unit analysis, process and procedure charting;

b) activity sampling, group timing and office standard data;

c) multiple linear regression analysis; and

d) economic measurements.

\section{4) GORDON MODEL}

Reference [21] uses the term ' $\mathrm{KW}$ effectiveness' instead of $\mathrm{KW}$ productivity and claims the term is broader and is a collection of factors better to portray what KWs do beyond the quantity of work. This broader term includes:

a) quantity (how much gets done);

b) quality (how well it gets done);

c) timeline (when it gets done); and

d) multiple priorities (how many things can be done at once).

A highly effective $\mathrm{KW}$ would score well on all four criteria [21].

5) DRUCKER MODEL

Reference [17] emphasized the potential limited application of Taylorism, including work design, and industrial engineering principles in measuring KW productivity. Reference [17], however, contributed by listing six factors that determine the productivity of $\mathrm{KW}$ :

a) KWs must identify the task themselves;

b) KWs need to have autonomy;

c) Innovation has to be part of knowledge work;

d) knowledge work requires continuous learning and teaching;

e) KW productivity is primarily a matter of quality, not just quantity; and

f) KWs should be seen as an asset instead of a cost.

Although [17] urges management to see KWs as assets, the model is essentially not a measurement-based methodology.

C. The need for an integrated approach to assessing knowledge workers

The dimensions in table III that the authors have focused on do not take into consideration some of the factors highlighted in table II. However, the common factors classified under the sub-elements of table II include autonomy under self-management by [34], [21], and [17]. Autonomy is the second highest ranking dimension captured under models in table III. 
The highest-ranking dimension in table III - quantity - is viewed and interpreted as an output perspective rather than a process perspective under table II.

It is evidently clear that there is an apparent gap between what researchers believe is important and what currently exists methodologically, suggesting important areas for future research. Similar gaps between the use and advocacy of the respective productivity dimensions also exist and can be seen.

In this regard, reference [14] claims: "Herein lies the dilemma of measuring the productivity of knowledge workers: purely scientific methods cannot quantitatively measure the critical factors of worker creativity, innovation, and motivation".

In summary, the existing models focused more on the output factors than the process factors in an attempt to assess $\mathrm{KW}$ productivity. Assessing output factors limits the ability to guide prospective and current $\mathrm{KW}$ on how to improve on their productivity.

The above discussions answer our RESEARCH QUESTION 2.

\section{CONCLUSION}

In developing countries, the number of knowledge workers is growing at unprecedented levels. This trend is similar to South Africa. In order to better comprehend and manage these growing numbers of knowledge workers, an understanding of their productivity requirements would be of value to organizations' planning and management.

In South Africa, there is a huge demand for these types of workers as opposed to manual workers as shown in table II and argued by the researchers.

A further understanding on what drives productivity of these growing type of workers is imperative to advance management knowledge and academic literature.

\section{FUTURE WORK}

In further exploring the research questions three and four, the researchers developed a rudimentary framework that can integrate the productivity 'process' factors. Interviews to the South African knowledge intensive organizations specifically Information Technology (IT) organizations will be conducted.

Productivity will be assessed at an individual level as opposed to Team or Organization. This is due to:

- time restrictions in tackling all the levels of teams, Organization and Economy

- the individual improvements in productivity are assumed to be linked to productivity and performance improvements at team, organizational level and ultimately economic level

- aiming the research at the lowest unit of measure, which is the individual would yield the most pertinence factors in addressing productivity without considering other elements like group dynamics.

In addition, the development of a framework that attempts to integrate all the relevant individual productivity factors to produce a single guidance of the knowledge worker's level of productivity is imperative.

\section{ACKNOWLEDGMENT}

The lead author is grateful to the supervisor for the continued guidance and support throughout this research topic and acknowledges a scholarship that was awarded by BankSETA to undertake a doctorate in business leadership at Unisa

\section{REFERENCES}

[1] Hendarman, A. F. and Tjakraatmadja, J. H. (2012) 'Relationship among Soft Skills, Hard Skills, and Innovativeness of Knowledge Workers in the Knowledge Economy Era', Procedia - Social and Behavioral Sciences, 52, pp. 35-44. doi: 10.1016/j.sbspro.2012.09.439.

https://doi.org/10.1016/j.sbspro.2012.09.439

[2] Davenport, T. (2003) 'A Measurable Proposal ; He's back-and Tom Davenport's betting on a new, big idea: knowledge workers are people too. Can their processes be quantified? Can we help their plight? This might just be the new reengineering.', CIO. United States; US, 16(16), pp. $46-48$.

https://doi.org/10.1126/sageke.2003.48.nw163

[3] Margaryan, A., Milligan, C. and Littlejohn, A. (2011) 'Validation of Davenport's classification structure of knowledge-intensive processes', Journal of Knowledge Management, 15(4), pp. 568-581. doi: $10.1108 / 13673271111151965$.

[4] El-Farr, H.K. (2009), "Knowledge work and workers: a critical literature review", Leeds University Business School, Working Paper Series, Vol. 1 No. 1 \& Mla'dkova', L. (2011), "Management of knowledge workers", Economics and Management, pp. 826-31

[5] Drucker, P. F. (1997) 'My Life as a Knowledge Worker', Inc.com. Available at: http://www.inc.com/magazine/19970201/1169.html.

[6] Davenport, B. T. H. (2006) 'Maximizing Knowledge Worker Productivity : The Next Generation of Management', Linkage Excellence in Management \& Leadership, pp. 1-38.

[7] Mládková, L. (2012b) 'Leadership in management of knowledge workers', Procedia - Social and Behavioral Sciences, 41, pp. 243-250. doi: 10.1016/j.sbspro.2012.04.028.

[8] Mládková, L. (2012a) Knowledge Workers in Manufacturing Sector. Available at: www.icmem.tk.

[9] Brinkley, I. et al. (2009) Knowledge Workers and Knowledge Work - A Knowledge Economy Programme Report, Knowledge Creation Diffusion Utilization. Available

at: http://www.theworkfoundation.com/DownloadPublication/Report/213_ 213_know_work_survey170309.pdf (Accessed: 31 May 2016).

[10] Jääskeläinen, A. and Laihonen, H. (2013b) 'Overcoming the specific performance measurement challenges of knowledge-intensive organizations', International Journal of Productivity and Performance Management. Bradford, United Kingdom, Bradford: Emerald Group Publishing Limited (Emerging Markets Case Studies Collection), 62(4), pp. 350-363. doi: 10.1108/17410401311329607.

[11] Wong, P. S. S. (2012) Drucker's knowledge-worker productivity theory : a practitioner's approach to integrating organisational work processes with Drucker's six major factors determining knowledge-worker productivity. Available at: http://epubs.scu.edu.au/theses/263/.

[12] Birks J, "FoCoFuture Forum: Managing Growth for a Robust Economy", presented City of Fort Collins, October 2015. https://static1.squarespace.com/static/5a6505f26957da1480ad2d8e/t/5a 79ee309140b7b7a84e3bdd/1517940277423/3_Jobs+for+a+Robust+Eco nomy_Josh+Birks.pdf. Date accessed. 25 October 2019

[13] Mládková, L. (2012a) Knowledge Workers in Manufacturing Sector. Available at: www.icmem.tk.

[14] Kelemen, J. (2010) 'On knowledge in context', in IEEE 8th International Symposium on Intelligent Systems and Informatics. IEEE, pp. 17-21. doi: 10.1109/SISY.2010.5647509.

[15] " South Africa GDP - composition by sector." The World Factbook. Central Intelligence Agency, 2018. Date accessed. 25 October 2019

[16] Van Staden, R. and Du Toit, A. (2011) 'Career development of South African knowledge workers', South African Journal of Economic and Management Sciences, 14(1), pp. 80-91. https://doi.org/10.4102/sajems.v14i1.97

[17] Drucker, P. F. (1999) 'Management', California Management Review, 41(2), pp. 79-94. doi: 10.1109/EMR.2006.1679053. 
[18] Mládková, L. (2014) 'Knowledge Strategy: Key Player or Relict of the Past?', Procedia - Social and Behavioral Sciences. Elsevier B.V., 150, pp. 628-636. doi: 10.1016/j.sbspro.2014.09.082

[19] Department of Labour, "Job Opportunity Index database 2011/12", http://www.labour.gov.za/DOL/downloads/documents/annual-reports/jo b-opportunities-and-unemployment-in-the-south-african-labour-market/ 2014/joboppreport2014.pdf. Accessed on 10 August 2016

[20] Davenport, T. H., Thomas, R. J. and Cantrell, S. (2002) 'The Mysterious Art \& Science of Knowledge-worker Performance', MIT Sloan Management Review, 44(1), pp. 23-30.

[21] Gordon, G. E. (1997) The Last Word on Productivity and Telecommuting, Gil Gordon Associates. Available at: http://www.gilgordon.com/downloads/productivity.txt.

[22] Berglind, B. L. and Scales, C. D. (1987) 'White-Collar Productivity: Seeing Through the Camouflage', Management Review, 76(6), pp. 41-46. Available

at: http://scholar.google.com/scholar?hl=en\&btnG=Search\&q=intitle:White -Collar+Productivity:+Seeing+Through+the+Camouflage\#0.

[23] Efimova, L. (2003) 'Knowledge worker paradox', Knowledge Board, 119378(October).

[24] Ramírez, Y. W. and Nembhard, D. A. (2004) 'Measuring knowledge worker productivity', Journal of Intellectual Capital, 5(4), pp. 602-628. doi: 10.1108/14691930410567040.

[25] Laihonen, H. et al. (2012) 'Measuring the productivity impacts of new ways of working', Journal of Facilities Management, 10(2), pp. 102-113. doi: 10.1108/14725961211218749.

[26] Palvalin, M. et al. (2015) 'International Journal of Productivity and Performance Management SmartWoW - constructing a tool for knowledge work performance analysis SmartWoW - constructing a tool for knowledge work performance analysis', International Journal of Productivity and Performance Management EuroMed Journal of Business Iss International Journal of Productivity and Performance Management, 64(4), pp. 479-498. Available at: http://dx.doi.org/10.1108/IJPPM-06-2013-0122 (Accessed: 1 June 2017).

[27] Erne, R. (2010) 'Does Knowledge Worker Productivity Really Matter ?', Knowledge Creation Diffusion Utilization, pp. 301-308. Available at: file:///C:/Dokumente und Einstellungen/bwillfort/Desktop/I-KNOW 2010/Knowledge Work/does_knowledge_worker_productivity_matter.pdf.

[28] Miller, D. B. (1977) 'How to improve the performance and productivity of the knowledge worker', Organizational Dynamics, 5(3), pp. 62-80. doi: 10.1016/0090-2616(77)90031-6.

[29] Bandura Albert (1994) 'Self-Efficacy', self-efficacy.

[30] Judge, T. A. et al. (2007) 'Self-efficacy and work-related performance: the integral role of individual differences.', The Journal of applied psychology, 92(1), pp. 107-127. doi: 10.1037/0021-9010.92.1.107.

[31] Drucker, P. F. (2006) 'Knowledge-worker productivity: the biggest challenge', IEEE Engineering Management Review, 34(2), pp. 29-29. doi: 10.1109/EMR.2006.1679053

[32] Gupta (1995),"Productivity measurement in service operations: a case study from the health-care environment", Managing Service Quality: An International Journal, Vol. 5 Iss 5 pp. 31 - 35 https://doi.org/10.1108/09604529510100468

[33] Mundel, M. (1975). Measuring and enhancing the productivity of service and government organizations. Tokyo: Asian Productivity Organization

[34] Bumbarger, W. (1984). Operational functional analysis: Do-it-yourself productivity movement. New York, NY: Van Nostrand Reinhold

[35] Smith, C. 1984. Awareness, analysis and improvement are keys to white-collar productivity. Industrial Engineering (Jan.):82- 91.

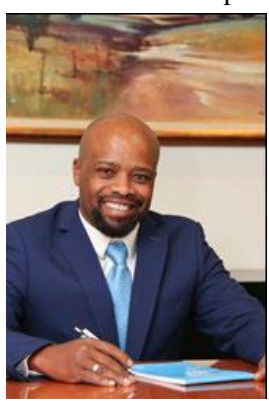

Mr A. T Molekoa was born in Johannesburg, South Africa. He has a Bachelors degree in Mechanical Engineering from University of Cape Town obtained in 2001, a Masters in Business Administration obtained from University of Pretoria - GIBS business school obtained in 2009. $\mathrm{He}$ completed a certificate in Corporate Governance with the University of Johannesburg in 2012. He currently is a doctoral candidate at the University of South Africa in Midrand South Africa. He also serves as the CEO of the thyssenkrupp Regional Office for Sub-Saharan
Africa, located in Johannesburg, since 2016.

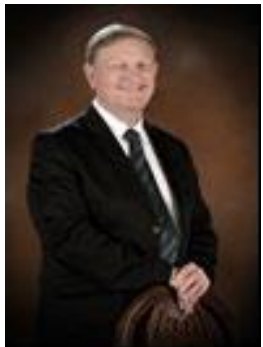

Prof J A (André) van der Poll holds a Doctorate in Computer Science obtained from the University of South Africa (Unisa). He is a professor in ICT Management at Unisa's SBL and his research interests are in the specification and reasoning of ICT management processes; the formalization of business process models, Business Intelligence, and Cloud Computing. $\mathrm{He}$ is the author of numerous journal articles and peer-reviewed conference papers and delivered many Doctoral and Master's students. He holds an NRF rating, 